\title{
THE ENGLISH SCANNING SKILL OF BILINGUAL AND MONOLINGUAL TOURISM STUDENTS IN DENPASAR TOURISM ACADEMY
}

\author{
Md. Yudyantara Risadi ${ }^{1}$, I Gede Astawa ${ }^{2}$, I Made Winia ${ }^{3}$, I Nengah Laba ${ }^{4}$ \\ ${ }^{1,2,3}$ Hotel Department, Denpasar Tourism Academy, Indonesia \\ ${ }^{4}$ Tourism Management, Institute of Tourism and Business International \\ yudyantara@akpar-denpasar.ac.id
}

\begin{abstract}
This study aimed at figuring out the access of Indonesian students to English and figuring out the difference of scanning skill possessed by bilingual students and monolingual students. The subject of this study was 31 2nd semester students from Denpasar Tourism Academy, Bali. The data was collected through a questionnaire and a provided test. The result of the questionnaire shows that students have more access to English through films, listening to English songs, computer games and their mobile phone when they are chatting. From the questionnaire is also found that $42 \%$ of the students were monolingual -they use Bahasa only at school and at home- and 58\% of the students were bilingual-they use Bahasa and local language-. The result of the test shows that students who are monolingual in that school outperform the bilingual with the average score is 78.00, meanwhile the bilingual students have the average score with score 64.00. It implies that the monolingual students can answer easily the questions given by the teacher than the bilingual students because the use of Bahasa Indonesia only helps them to understand the instruction
\end{abstract}

Keywords: Bilingual Students; Monolingual Students; English Scanning Skill

\section{INTRODUCTION}

Globalization has made it possible to have rapid contact of languages. The use of many languages appears not only in formal events like school and government, but also in informal way as they are spread widely on the use of media and daily social communication (Rosselli, Ardila, Jurado, Salvatierra, 2013). Language speakers do select which language is to learn and which is not based on individual needs. Due to the needs of language usage, Indonesia must consider that English, a broadly used language around the world, as a bridge to enter the international communication. It is supported by Nishanthi (2018), who state that English is probably the most popular foreign language to be learned in Indonesia because of some reason. First, English is the international language to communicate in order to get in touch on an international level. Second, English is also necessary for the field of education. In many countries, children are taught and encouraged to learn English as their second or foreign language for some countries as it is the dominant language in the sciences. Third, learning English is important as it gives access to over half the content on the internet. Knowing how to read English will 
allow access to billions of pages of information which may not be otherwise available. Fourth, resources make learning English easy. Laba (2017) states that the rapid development of science and technology as well as telecommunication tools in digital era needs the mastery of English. He further remarks that having good and effective communication ability in English is a necessity. Knowing and realizing the important role of English, students should be sufficiently equipped with communication skills in English, both in writing and speaking. Many people think that it is very difficult and confusing, in fact English is actually the easiest language in the world to be learned because there are so many accessible resources are available. Last but not least, English is the dominant business and travel language and it has become almost a necessity for people to speak English if they are to enter a global workforce and have a desire to travel around the world. Research from all over the world shows that cross-border business communication is most often conducted in English and many international companies expect employees to be fluent in English. That's some reasons making people learn English and make it important to be mastered (Nishanthi, 2018).

The importance of English cannot be denied and ignored since English is the greatest common language spoken universally. Knowledge of English is necessary if one wants to come up in life. It is the major window of the modern world. This is all true due to the fact that the advanced countries have opened their doors for recruiting technically qualified people. Commonly, only those who have a command over the English language are given a job (Nishanti, 2018). It is generally believed that English as a foreign language (EFL) plays a crucial role in educational system of the world (Gorjian \& Sayyadian, 2017). Having access to learning in more than one language also allows individuals to use different languages for different functions. For example, literacy in national and/or international languages often opens doors to the world of work and facilitates mutual intelligibility between the local context and the "outside world" politically and culturally (Risadi \& Ardiasa, 2020). Thus, Indonesia has set English as a foreign language to be taught in many levels of education as an effort in fulfilling qualified human resource. In fact, learning English requires constant practice, patience, and access to the language itself. A lot of parents have registered their children to English courses or bilingual schools to help them get good English grades at school and a lot of exposures to English language (Da Silva, 2014). It can be seen that parents' ambition and situation are being able to see their children to win the competition in the job market in the future. Other contacts to English language can also be accessed by listening to English songs, watching English movie, playing the game, the internet, reading and listening to the advertisement. All those strategies were chosen by learners as their subconscious process of acquiring foreign language especially English language. Engish acquisition was the primary aspect of language learning that benefited from listening to songs, followed by listening skills. Moreover, well-selected movie materials could enhance students' language learning process and increase their motivation to learn the target language (Patahuddin, Syawal, and Bin-Tahir, 2017). In fact, as it is put in a foreign language level, students don't seem to give any special attention in using English to their daily life, although English is easily found in almost all aspects, written and spoken platform of students' social life out of school. Most of the students study English just in the point of view for the examination and it is only learned for the importance 
of getting higher score as it is required in the school curriculum. Furthermore, sufficient practices and exposure on English language learning are not given to students to learn English properly. It may assume that the exposure of English can be one of the factor that makes students learn English better and get better score in the class (Da, Silva, 2014).

Nowadays, Indonesian latest students is more exposed to English than the past generation, such as our parents or grandparents, especially for those students who live in multicultural city like Jakarta, Bandung, and Bali. In education field, students in Bali learn English at least once a week within around fifty to sixty minutes per session, even kindergarten students have started learning simple vocabularies of English at their school (Zacharias, 2010). Besides, nowadays students see and read many English text around them, for instance, in billboard, internet, newspaper, and magazine, they also hear many English word from television or from their mobile phone (Gorjian \& Sayyadian, 2017). Bali as the island of many tourism activities must consider that possessing international language is urgently needed. Thus, English is such an important language that Balinese people have to own. One of the strategies in facing this situation is by providing tourism-based schools and courses that includes English language as the must be-learned issue. In Bali, tourism students are faced in a condition in which they should have a direct contact with many tourists who come from other countries. However, they experience another more common linguistics fact in the environment: the mixed use of Indonesia and English language in their environment (Asrifan, Jabu, Atmowardoyo, Chen, 2017). As the impact, the students sometimes code-switching when talking to their friends through social media, daily conversation, or mobile phone without following a fixed pattern (Lucero, 2015). Hence, Indonesia belongs to the expanding circle which means that Indonesia uses the English as the foreign language and do not use it as daily contact habit in communication (Abdurahman, 2016).

However, there do not seem to be any parallel relationship between the increasing contact to English and the Indonesian students' English competence, specifically in terms of reading skill. That can be due to several factors such as the status of English as foreign language, cultural values, lack of facilities and practices, and all of which might lead to the very rare use of English language. In cultural values, most families in Indonesia do not communicate in English. They are considered as monolingual because they only use Bahasa as their national language. Besides, some of Indonesian also have their own mother tongue or it is called by local languages that they acquire from their family and environment in daily conversation and social events (Da Silva, 2014). This situation also occurs in Bali where the people, including tourism students in this case, speak 2 languages -Bali as their mother tongue and Bahasa Indonesia- or it is called by bilingual. Reading skill for both monolingual and bilingual is important to be taught because it is a key factor that affects the academic success of students significantly because they read every day and even when they access their phone. In relation to reading skill, it can be regarded as a cognitive input behavior for all courses (Shamir \& Siavoshi, 2014). It is expected that a student who is able to comprehend what he/she reads to be successful in other school subjects as well as the English language course and it also can help the students to gain or receive meaningful information within text, but the problem of teaching them is always raising because reading which has been a 
part of the English culture is absent from the culture of most ethnic groups in Indonesia. As the result, reading is not the usual habit and need of most families in Indonesia, especially for those who live in rural area. Besides, reading skill is of critical value in the life of modern man. Mostly, problem of reading is their comprehension. Students difficult to understand meaning of the text and they cannot focus on what they read during the reading activity and still have difficulty to get purpose of the text. Another problem is that not every detail of information in the passage is needed to answer the reading questions but students usually read the reading passage word by word (Aritonang, Lasmana, Kurnia, 2018).

In today's condition, people are inundated by text messages and can hardly imagine a life free of written text which in turn creates typical problems for the Indonesians learning English reading skills. To be a good reader, one needs to employ the reading skills. According to Munby in Da Silva (2014), who proposed a typology of language skills, reading skills are considered to be macro-concepts consisting of several skills, one of which is the scanning skill. In the simplest word, this skill means that they do not have to read every word and line; on the contrary, such an approach would stop them scanning successfully. Scanning is carried out within a short period of time, and becomes a step toward a further and deeper reading activity. Then, scanning is the basic skill of reading. Then, scanning is usually learned first in EFL reading classes. Scanning is a type of reading skills that is characterized by activities of searching a specific information in a text (Aritonang, et al., 2018). The examples of scanning tasks can range from searching for one's name, specific date, number, place, or particular words. Scanning can help a reader to choose which text he or she would like to read and to become efficient reader who select reading materials to serve his/her reading purpose. In addition, Students need to be able to scan the text particular bits information they are searching for and students also need to skim a text as if they were casting their eyes over its surface to get a general idea of what it is the topic and conclusions. Besides that reason, another thinks that makes researcher interested in conducting this research is the research of a qualitative research to found of successful in implementing skimming and scanning strategies in teaching reading text (Asrifan, et al., 2017). Scanning is alternative ways to teaching reading comprehension, and by some researchers believed that students like scanning technique in learning reading comprehension because it shall help they to ease in the answer the test with used multiple choice form or open ended question, they will answer the question quickly. In fact, there some reading strategies that can be used other than scanning, they are skimming, anticipation and prediction, general and specific statement, irrelevant sentences, references and restatement and strong reading comprehension strategies, especially for college and graduate students who often have to complete extremely long readings each week could be very important. In experienced students are sometimes overwhelmed by their intimidating reading assignments.

Many researchers believe monolingual and bilingual have different perspective or strategy in doing their English language task at school or home. Yamchi and Kumar (2016) identify that bilinguals - possesses 2 languages- may show a disadvantage in remembering linguistic information relative to monolinguals, which may be due to bilinguals having a deficit in certain linguistic processes. In contrast, bilinguals may be advantaged in remembering nonlinguistic information and that better nonverbal recall in bilinguals maybe due to their better 
executive control. They finally found that monolingual performed better than bilingual because the existence of one language can help the students to understand the instruction or even the meaning of English language in the text because many Bahasa Indonesia has almost the same meaning with English Language, such as Apel with Apple or Efek with Effect. It means the monolinguals have better positive effect on certain aspects of linguistics processing when they get a task from English language. In relevance with this statement, Gorjian and Sayyadian (2017) also believe that there is a superiority of monolingual and bilingual when reading comprehension is given in the classroom. It is caused by there is many different structures of vocabulary and grammar between students' mother tongue and English language. Another important point about students with bilingual ability is that they have only control over their spoken language and they may know only a little about the written from of their language. Da Silva (2014) added that in scanning skill, monolinguals performed better than bilingual shown by the difference of mean score gained by the students. It is likely because of using Indonesian as the only language spoken both at school and at home supports the monolinguals' scanning skill acquisition and according to Jalalipour, Majdinasab, Khedri, \& Chadorian, (2017), they found that the environment of monolingual students is supported by many resources of English language because the educational level of monolingual students' parents in some activities such as storytelling to children and being interested in participating in reading activities, such as reading newspaper, it seems that monolingual children were in better educational and environmental conditions for acquiring reading skills. Reading proficiency, in this research, scanning skill is undoubtedly crucial to academic success, and students definitely need guidance and practice in order to become efficient readers (Gorjian \& Sayyadian, 2017). Reading skills for college students offer some advice and practice which may help these students achieve their goals, in this case their scanning skill. Currently, English is taught in every level of students' grade and based on some researchers pointed above, the researcher wonder how the increasing contact with English will affect the reading skill of the tourism learners. Thus this research is aimed at finding out the access of Indonesian learners to English, and the comparison of the Indonesian bilingual and monolingual students' performance on the English reading skills, particularly their scanning skills.

\section{METHODOLOGY}

The study was conducted at Denpasar Tourism Academy, an tourism academy in Denpasar regency on second semester and started on 28th of January, 2020. The subject was 31 students of second semester students. They came from diverse ethnic groups: Balinese, Javanese, and Sasak. Their ages were between 18 to 20 years old. 6 students were 18 years old, 20 students were 19 years old, and 5 students were 20 years old. In term of sex, this class consist of 15 male students and 16 female students. Convenient sampling was used for this research due to time allotment and financial restriction (Da Silva, 2014).

Table 1. The Data of Students' Ages

Students Ages




\begin{tabular}{cc}
\hline 6 students & 18 years old \\
20 students & 19 years old \\
5 students & 20 years old \\
\hline
\end{tabular}

The first step of this research was conducting a small survey consisting of open-ended questions in Bahasa about the subject's identities and language background was conducted on 11th of February 2020. This step was done in order to find out which students are bilingual and monolingual. It can be seen from their answer in the open-ended questionnaire. This questionnaire was adopted from Da Silva (2014). This questionnaire also gives the information about subjects' contact toward English, their attitude toward English, and subjects' language background. The questionnaire made in Bahasa Indonesia because it is the common language used by the students in order to make them understand easily. Afterwards, the subject was given a test of scanning skill on 21th of February 2020. This test was also adopted from Da Silva (2014). This test consists of 2 parts, first is about people's job. The question of this part consists of 5 columns and 5 rows. The first columns consists the people's name and the first row consists of "Name", "Job before", "Current Job", "Years", and "Reason". The first column, entitled Name, consisted of the names of the people in the text. The second column, entitled Job before, required the participants to fill in with the five people's previous jobs. The third column, labeled Job now, was to be filled with the five persons ${ }^{\text {ee }}$ present jobs. The fourth column, titled Years, should state the number of years each person has spent for the present job. The fifth column, labeled Why in job, required the students to write each person's reason for choosing their last job. One example was given for each column so that the participants had a specific guide that would help them connect each of the title of the column with the specific information available in the text. Making the best use of the examples, students were expected to be able to find particular information in the text to fill in to the appropriate column. This was chosen because they are tourism students and after being graduated, they will find a job and this test is provided in order to make the students familiar with word "Job".

The second is about the description text of Saudi Arabia. Saudi Arabia was chosen because it is one of the best tourism places of the world, since this test was to measure the scanning skill of tourism students, the description of Saudi Arabia will be appropriate to be used. Following the text was an incomplete form into which participants had to write specific information about Saudi Arabia: its capital city, area, head of state, official religion, language, currency used, holy places, exports, climate, and average yearly rain fall on spaces provided. All in all, the test required participants to find specific information concerning people's jobs, and a general description of a country. Additionally, in this text, students were required to answer 10 questions which can be easily answered if the students do the scanning skills. Then, the result of the data will be analyzed by using Ms. Excel to find out the percentage of the students and the mean score.

\section{RESULTS AND DISCUSSION}

After distributing the questionnaire in order to find out subjects' language background, their contact and attitude towards English, the results were gained 
well. The questionnaire reveals that the variety language used by the subject within their environment. The result of the questionnaire can be seen in Table 2 .

Table 2. The Result of Variety Language Used by The Subject

\begin{tabular}{ccc}
\hline Students & Total & Percentage \\
\hline Monolingual & 13 Students & $42 \%$ \\
Bilingual & 18 Students & $58 \%$ \\
\hline
\end{tabular}

$42 \%$ of students were monolingual, they only use Bahasa in their daily communication with people around them. It was also found that $58 \%$ students were bilingual comprise speakers of other ethnic languages. The detail of the language used by the bilingual students can be seen in Table 3 .

Table 3. Language Used by Bilingual Students

\begin{tabular}{ccc}
\hline Language & Total & Percentage \\
\hline Bahasa and Bali & 10 & $55 \%$ \\
Bahasa and Java & 5 & $28 \%$ \\
Bahasa and Sasak & 3 & $17 \%$ \\
\hline
\end{tabular}

$55 \%$ of the bilingual also speaks Bali language, $28 \%$ of the bilingual speaks Java language, and $17 \%$ of the bilingual speaks Sasak language. The bilingual tourism students may be categorized into simultaneous early bilingual students in which they acquire the local language that their parents speak. The monolingual students may be classified as they are able to speak Bahasa first before learning English. However, Denpasar Tourism Academy can be considered to conduct a bilingual education because they use Bahasa and English as an instruction in the class.

It is also interesting to be noted that the monolingual students (use Bahasa only in daily communication) state that they have many contacts with English. $62 \%$ (8 students) of the monolingual students use English 1 to 10 hours a week, 31\% (4 students) of the monolingual students use English 11-15 hours a week, and 7\% (1 student) of the monolingual students use English more than 15 hours a week. The detail of contact of English done by the monolingual tourism students can be seen in Table 4.

Table 4. Hours of Contact to English in Daily Activities by Monolingual Students

\begin{tabular}{ccc}
\hline Hours & Students & Percentage \\
\hline 1 to 10 hours a week & 8 students & $62 \%$ \\
$11-15$ hours a week & 4 students & $31 \%$ \\
More than 15 hours a & 1 students & $7 \%$ \\
week & & \\
\hline
\end{tabular}

According to the questionnaire, it is also perceived that they use English in many activities in formal or informal situation, they use it in school when interacting with their lecturers or in English courses with their tutor. Other activities or access that they use English are in listening to the music and singing it, playing computer games, chatting with their friends, make a caption in English, and when 
talking with their peers. Moreover, regarding to their attitude towards Bahasa and English, $71 \%$ of the students were proud of using both English and Bahasa. 19\% of the students were proud to be able to speak English than Bahasa, and 10\% of the students were proud of their ability to speak Bahasa.

On the other hand, the bilingual students shows more contact than monolingual. 56\% (10 students) of the bilingual students use English 1 to 10 hours in a week, 28\% (5 students) of the bilingual use English 11 to 15 hours in a week, and $16 \%$ (3 students) of the bilingual use English more than 15 hours in a week. The detail of contact of English done by the bilingual tourism students can be seen in Table 5.

Table 5. Hours of Contact to English in Daily Activities by Bilingual Students

\begin{tabular}{ccc}
\hline Hours & Students & Percentage \\
\hline 1 to 10 hours a week & 10 students & $62 \%$ \\
$11-15$ hours a week & 5 students & $31 \%$ \\
More than 15 hours a & 3 students & $7 \%$ \\
week & & \\
\hline
\end{tabular}

The activities that they do when they use English are more likely the same with what the monolinguals do. However, more hours were devoted to watch the TV cable such as Nickelodeon, HBO, Cartoon Network, or Disney Channel and even looking an advertisement on the internet can be one of their contact to English language. One students, Kodi (pseudonym) stated that he used English with foreigner and another student from Malaysia, Madi (pseudonym) stated that he only use English when exam is conducted with the teacher. This finding related to access to English in daily activities is relevance to Patahuddin, Syawal, and Bin-Tahir (2017) who found that EFL learners' strategy in learning English language such as practicing English dialogue through phone, doing the assignment on the internet, memorizing and writing practice on watching movie, reading English text in movie subtitle, practicing English pronunciation, learning English tenses, English translation exercise. In addition, the Indonesian EFL learners acquired English vocabulary through the dictionary, reading English book, listening to and watching English songs and movies, playing the game, the internet, and reading English advertisement. This finding is also supported by Rintaningrum, Aldous, and Conway (2016) who states that the availability of books, journals, literature, novels, comics, computer, internet, audios, CD, DVD, cassette, tape recorder and English TV channels at home may have an influence on the speed of English language learning, especially their reading skill because when they see something, they simultaneously reading something. The access to English also help the students to know the new rules or pattern that sometimes imply when they are learning English in the classroom. In conclusion, the tourism students have a good learning efficiency. The result shows willingness to use several kinds of learning and acquisition strategy thus, it can be interpreted that students have positive attitude toward English language.

After distributing the questionnaire, the test was given in order to check the tourism students' scanning skill ability. The test of the scanning skill showed that 
the monolingual students have better score than the bilingual students. The result of scanning skill can be seen in Table 6 .

Table 6. The Result of Test

\begin{tabular}{c|c}
\hline Students & Mean Score \\
\hline Monolingual & 78.00 \\
Bilingual & 64.00 \\
\hline
\end{tabular}

The average score of monolingual students was 78.00 and the bilingual students have the average score is 64.00. For the first part in question, the total score was 20 and the monolingual students' average score was 16 in the first part, and the bilingual students' average score was 11 in first part. For the second part, the total score was 10, and the monolingual students' average score was 7 and the bilingual students' average score was 6. The findings were supported by Aquino in Da Silva (2014) who indicated that monolingual students had better score in English test than the bilingual. Both of them stated that using Bahasa as the only language for instruction both at school and at home can help the students in acquiring the specific information when scanning the text. This finding is also supported by Yamchi and Kumar (2016) who stated that the place of origin -where acquire the first languagemay also become a determining factor in the mastery of a foreign language, in this context English language. This finding is also related to Gorjian and Sayyadian (2017) who found that when the instruction is given by Bahasa, the monolingual students tend to receive better understanding than the bilingual students because they are familiar with the words and sentences which are given in their daily communication. On the other hands, the bilingual students find it difficult because they are still processing the instruction and try to comprehend how to finish the task faster because they get a kind of competition when they are facing a game with the monolingual students. They also add that bilingualism may not have any direct effect on better comprehending of English texts, since their mother tongue languages (Sasak, Bali or Java) seem to have different structures and vocabularies with English language, they are unlikely to have any direct mutual effect on one another. It differs with Bahasa Indonesia and English language, these language seem to have many similarities in many words. Another important point to tell about the bilingual students is that they tend to have only control over their spoken language and they may know only a little about the written from of their language because their parents usually speak the language in form of verbal communication and yet few of written form. Thus, the comparison which is performed in this study is not comparing the result of a completely acquired language on reading comprehension of English. In fact, it somehow shows the influence of the spoken form of one language on reading comprehension of another language (Gorjian \& Sayyadian, 2017).

Meanwhile, the first part of the test required the subjects to complete a table containing information on the previous and recent job, the duration, reason for choosing the job. It can be seen from the answers of the students that many mistakes was found in the column "Reason", for the bilingual students, $50 \%$ did the mistakes in column "Reason" and $46 \%$ of the monolingual students did the mistake in column "Reason". From this finding, it can be seen that the students may not focus on the text when they had to find out the reason for that person chose the job. It 
indicated that the students have lack of knowledge of understanding the meaning of "Reason" in this part. In addition, in the second part, most of students made mistakes in finding the specific information about "climate, currency, and head of state". 54\% of monolingual students and $61 \%$ of bilingual students answered climate with "average rainfall". $38 \%$ of monolingual students and $50 \%$ of the bilingual students answered currency with "Saudis", and $69 \%$ of monolingual and bilingual students answered the head of state with "Royal Family". From this scanning skill test, it was also found that, the monolingual students outperformed the bilingual students indicated by the number of the students who made the mistakes in answering the question. This finding is supported by Jalalipour, Majdinasab, Khedri, \& Chadorian, (2017) who found that bilingual students tend to make mistake in answering a question because the environment or situation of bilingual students makes them not to have the opportunity to become competent and fluent in English language before they enter the tourism academy. As result of this environment, they do not acquire some important skills of comprehension and reading accuracy that is equal status with their monolingual friends and this environment including the level education of parents, they found that the education of monolinguals students' parents is mostly higher than the bilingual students' parent. This situation makes monolingual students are in better educational and environmental situations for acquiring reading skills. Meanwhile, Yeganeh and Malekzadeh (2014) believe that bilingual students have different mental abilities and greater cognitive flexibility to make comparison between two languages to read more efficiently in contrast to monolingual students. In other words, the bilingual subject's first language plays a crucial role in their performance, reading ability, and learning a foreign language. Additionally, bilingual students have to be able to immediately identify the language to which the speech they hear belongs, in order to process the input in correct way, be it to learn properties in that language or later to process them during language comprehension (Hohle, Babic, \& Nazzi, 2020). From those experts' statement, it is agreed that the further research must be conducted in order to find out more data and more analysis to find out the right decision about monolingual and bilingual students in the classroom activity.

For additional information, in processing and answering a meaning of the target language, in fact, it can be perceived well for both monolingual and bilingual students if their attention to meaning and form of sentences are concerned well. Tourism students should be encouraged by some stimulus to focus more on the content words and process them more deeply since deeper processing and understanding are associated with better reading comprehension and scanning skill, then focus on the lexical form does have a positive effect on comprehension. This means that using input enhancement techniques such as textual input enhancement could positively affect comprehension especially if the content words are targeted. As long as the students focus on the meaning of the word or sentences, both monolingual and bilingual students can do their best performance in doing the task (Karimi, Zangani, \& Fallah, 2019). The contribution of this study is to add additional information about teaching strategies for teacher in conducting learning process in the classroom for both monolingual and bilingual. 


\section{CONCLUSION}

Indonesian tourism learners are more exposed to English through many factors in their environment such as hand phone, peers, English songs, computer games, and film. These factors make the learners to do code-mixing or codeswitching or in this context they are able to be a bilingual people. The study showed that monolingual students had better average score compared to their bilingual counterparts. This probably was caused by the use of Bahasa Indonesia only in both school and home. Bilingual students tend to do mistake in answering a question. Tourism students should be encouraged by some stimulus to focus more on the content words and process them more deeply since deeper processing is associated with better reading comprehension and scanning skill. Then focus on the lexical form does have a positive effect on comprehension. Further study is required to find more data to have more clear explanation of the reason why monolingual students outperformed the bilingual students in terms of reading skill. The limitation of this present study is that this study can't be used a basis of representative of bilingual and monolingual students in Indonesia due to limited scale and comprehensive research instrument. For the further investigation, it is expected to have more application of relevant statistical analysis of standardized English test to wider population.

\section{REFERENCES}

Abdurahman, N. H. (2016). An Investigation of Code-mixing in Expanding Circles: Indonesians' Tweets. Connecting Professionally on ELT in Asia: Crossing the Bridge to Exellence (pp. 178-183). Vladivostok: FEELTA.

Ardila, A., Jurado, M. B., Roseli, M., \& Salvatierra, J. L. (2012). Cognate facilitation effect in balanced and non-balanced Spanish-English bilinguals using the Boston Naming Test. International Journal of Bilingualism, 0(0), $1-14$.

Aritonang, I. R., Lasmana, S., \& Kurnia, D. (2018). The Analysis of Skimming and Scanning Technique to Improve Students in Teaching Reading Comprehension. Professional Journal of English Education, 1(2), 101-106.

Asrifan, A., Jabu, B., Atmowardoyo, A., \& Chen, Y. (2017). Analysis of Students' Perceptions of Bilingual-Based Materials in English for Educational Technology in Indonesia. International Journal of English Linguistics, 7(6), 204-212.

Bahr, R. H., Silliam, E. R., Danzak, R. L., \& Wilkinson, L. C. (2014). Bilingual spelling patterns in middle school: it is more than transfer. International Journal of Bilingual Education and Bilingualism, 5(2), 1-19.

Da Silva, A. M. (2014). The English Scanning Skills of Bilingual and Monolingual Indonesian Students. Indonesian Journal of Applied Linguistics, 3(2), 5062.

Gorjian, B., \& Sayyadian, M. (2017). A Comparative Study on Bilinguals and Monolingual Learner' Reading Comprehension. Journal of Applied Linguistics and Language Learning, 3(1), 9-16.

Höhle, B., Bijeljac-Babic, R., \& Nazzi, T. (2020). Variability and stability in early language acquisition: Comparing monolingual and bilingual infants' speech 
perception and word recognition. Bilingualism: Language and Cognition, 23(1), 56-71.

Jalalipour, M., Majdinasab, F., Khedri, H., \& Chadorian, B. (2017). A Comparison of Reading Accuracy and Reading Comprehension in Bilingual Arabic/Farsi-speaking and Monolingual Farsi-speaking Elementary Students in the Fifth Grade. Journal of Rehabilitation Sciences and Research, 4(4), 97-101.

Karimi, M. N., Zangani, E., \& Fallah, N. (2019). Differential Allocation of Attention to Meaning and Form in Reading Comprehension for Monolingual and Bilingual Learners of English. TESOL International Journal, 14(1), 79-90.

Laba, I N. (2017). Developing Students' Essay Writing about Tourism Topics through Word Clustering Technique. Journal of Business on Hospitality and Tourism.Vol. 3 No. 1. 96-126

Lucero, A. (2015). Dual Language Teachers' Use of Conventional, Environmental, and Personal Resources to Support, Academic Language Development. International Bilingual Research Journal, 3(8), 107-123.

Nishanthi, R. (2018). The Importance of Learning English in Today World. International Journal of Trend in Scientific Research and Development, 3(1), 871-874.

Patahuddin, Syawal, \& Bin-Tahir, S. Z. (2017). Investigating Indonesian EFL Learners' Learning and Acquiring English Vocabulary. International Journal of English Linguistics, 7(4), 128-137.

Rintaningrum, R., Aldous, C., \& Conway, R. (2016). I Find It Easy To Learn English When ......... Lecturers' Perspective. Jambi International Seminar on Education 1 (JISE) (pp. 14-21). Jambi: Jambi University Press.

Risadi, M. Y., \& Ardiasa, I., K. (2020). The Use of Mother Tongue for Education Field in Multilingual Society, Bali-Indonesia. International Journal of Linguistics and Discourse Analysis (IJOLIDA), 1824.

Shamir, A. S., \& Siavoshi, Z. (2014). Reading Performance and Academic Achievement in Early Childhood Bilingual and Monolinguals. Open Journal of Applied Sciences, 347-353.

Yamchi, R., \& Kumar, V. (2016). Comparison of Iranian Monolingual and Bilingual EFL Students' Listening Comprehension in Terms of Watching English Movie with Latinized Persian Subtitles. English Language Teaching, 9(5), 65-76.

Yeganez, M. T., \& Malekzadeh, P. (2014). The Effect Of Bilingualism On The Developing Of English Reading Skill. Procedia - Social and Behavioral Sciences 192, 2(3), 803-810.

Zacharias, N. T. (2010). Issues of TEYL in Indonesian and what parent can do about it. Indonesian Journal of ENglish Language Teaching, 6(2), 75-88. 